\title{
Nanoscale study of As biomineralization in an acid mine drainage system
}

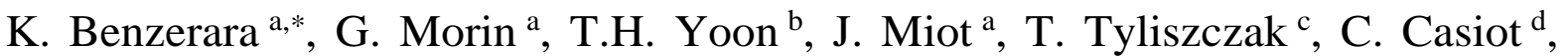 \\ O. Bruneel ${ }^{\mathrm{d}}$, F. Farges e,f, G.E. Brown Jr. f,g \\ a Institut de Minéralogie et de Physique des Milieux Condensés, UMR 7590, CNRS, Universités Paris 6 et 7, IPGP, Paris, France \\ ${ }^{\mathrm{b}}$ Laboratory of Nanoscale Characterization E Environmental Chemistry, Department of Chemistry, Hanyang University, Seoul 133-791, \\ South Korea \\ ${ }^{\mathrm{C}}$ Chemical Sciences Division, Lawrence Berkeley National Laboratory, One Cyclotron Road, Berkeley, CA 94720, USA \\ d Laboratoire Hydrosciences Montpellier, UMR 5569, CNRS, Universités Montpellier 1 et 2, IRD, Montpellier, France \\ e Muséum National d'Histoire Naturelle, USM 201 and CNRS UMR 7160, Paris, France \\ ${ }_{\mathrm{f}}^{\mathrm{f}}$ Surface $\mathcal{E}$ Aqueous Geochemistry Group, Department of Geological and Environmental Sciences, Stanford University, Stanford, \\ CA 94305-2115, USA \\ ${ }^{\mathrm{g}}$ Stanford Synchrotron Radiation Laboratory, 2575 Sand Hill Road, SLAC, MS 69, Menlo Park, CA 94025, USA
}

\begin{abstract}
Spatial and seasonal variations of the oxidation of Fe(II) and As(III) have been previously documented in the Carnoulès (Gard, France) Acid Mine Drainage (AMD) by bulk analyses. These variations may be correlated with the variations in the activity of indigenous As(III)- and Fe(II)-oxidizing bacteria living in the As-rich Carnoulès water. The activity of these bacteria indeed plays an important role in the nature and composition of the solid phases that sequester arsenic at this site. In order to better understand the interactions of microbes with Fe and As in the Carnoulès AMD, we combined Transmission Electron Microscopy (TEM) and Scanning Transmission X-ray Microscopy (STXM) to collect near-edge X-ray absorption fine structure (NEXAFS) spectra at high spatial and energy resolution and to perform high spatial resolution imaging at the 30-50 nm scale. Spectromicroscopy was performed at the C K-edge, Fe L2,3-edge, and As L2,3-edge, which allowed us to locate living and/or mineralized bacterial cells and to characterize Fe and As oxidation states in the vicinity of those cells. TEM was used to image the same areas, providing higher resolution images and complementary crystallographic and compositional information through electron diffraction and EDXS analysis. This approach provides unique information on heterogeneous geochemical processes that occur in a complex microbial community in an AMD environment at the micrometer and submicrometer-scale. Bacterial cells in the Carnoulès AMD were frequently associated with mineral precipitates, and a variety of biomineralization patterns were observed. While many mineral precipitates were not associated with bacterial cells, they were associated with pervasive organic carbon. Finally, abundant biomineralized organic vesicles were observed in the Carnoulès AMD. Such vesicles may have been overlooked in highly mineralized extreme environments in the past and may represent an important component in a common biomineralization process in such environments.
\end{abstract}

\section{INTRODUCTION}

Acid Mine Drainage (AMD) is generated by the microbially catalyzed oxidization of sulfide minerals (usually

\footnotetext{
${ }^{*}$ Corresponding author. Fax: +33144273785.

E-mail address: karim.benzerara@ impmc.jussieu.fr (K. Benzerara).
}

pyrite and arsenopyrite) exposed to the atmosphere and meteoric waters in metal sulfide mines and associated mine wastes (e.g., Evangelou and Zhang, 1995; Williams, 2001). The resulting waters are highly acidic and enriched in sulfates and in ferrous iron. The dissolution of As-bearing sulfides can also release As(III) and heavy metals which cause major environmental problems. The subsequent 
transformations of those pollutants in AMD systems and the processes immobilizing them have received special attention with regard to their geochemistry, mineralogy, microbiology, and genomics with the aim of designing efficient remediation protocols. AMD systems and some chemically similar (acidic and As-rich) hydrothermal springs are also interesting models for low-diversity extreme environments in which adapted microbial communities thrive and drive geochemical cycles (e.g., Baker and Banfield, 2003). Studying the release of sorbed or surfacebound As, one of the highly toxic elements in these systems, is of particular interest; its molecular-level speciation, which is responsible for its degree of toxicity and geochemical behavior, is controlled by a complex interplay between biotic and abiotic reactions. The predominant species of arsenic in AMD systems are arsenite, $\mathrm{H}_{3} \mathrm{As}(\mathrm{III}) \mathrm{O}_{3}{ }^{0}$ ( $\mathrm{pH}<9$ and depending on $\mathrm{pE}$ ), which is highly toxic and relatively soluble, and two forms of arsenate, $\mathrm{H}_{3} \mathrm{As}(\mathrm{V}) \mathrm{O}_{4}$, and $\mathrm{H}_{2} \mathrm{As}(\mathrm{V}) \mathrm{O}_{4}{ }^{-}$(depending on $\mathrm{pH}$ and $\mathrm{pE}$ ), which are less toxic, less soluble, and sorb more strongly than $\mathrm{H}_{3} \mathrm{As}$ ( III) $\mathrm{O}_{3}{ }^{0}$ to positively charged iron oxyhydroxides under acidic conditions $(\mathrm{pH}<5)$ (Dixit and Hering, 2003). As(III) oxidation is slow especially under acidic conditions (Eary and Schramke, 1990), but it can be catalyzed by diverse microorganisms including Thiomonas sp. (Ilyaletdinov and Abdrashitova, 1981; Simeonova et al., 2004; Bruneel et al., 2003; Battaglia-Brunet et al., 2006; Inskeep et al., 2007; Budinoff and Hollibaugh, 2008). As both $\mathrm{As}(\mathrm{V})$ and As(III) can be sorbed (either adsorbed or coprecipitated) mostly by hydrous ferric oxides (Dixit and Hering, 2003; Ona-Nguema et al., 2005), variations in the composition of microbial communities and thus variations in the relative rates of As oxidation and mineral precipitation can lead to spatial and seasonal variations in arsenic speciation in the solid phases. Such variations have been documented by bulk EXAFS studies in the Carnoulès AMD, Gard, France (Morin et al., 2003; Morin and Calas, 2006).

The Carnoulès AMD results from the percolation of water through sulfide-rich mining tailings (Leblanc et al., 1996). The acidic Reigous Spring ( $\mathrm{pH} 2.5-4)$ that flows through the mine site is strongly enriched in $\mathrm{Fe}(0.5-$ $\left.1 \mathrm{~g} \mathrm{l}^{-1}\right)$, sulfate $\left(1-3 \mathrm{~g} \mathrm{l}^{-1}\right)$, and arsenic (80-350 $\left.\mathrm{mg}^{-1}\right)$ (Leblanc et al., 1996). At $30 \mathrm{~m}$ downstream, 20-60\% of the As has been removed by the formation of authigenic yellow to orange As-rich (up to $22 \mathrm{wt} \%$ As) sediments. These sediments are rich in ferric iron hydroxysulfates, whose structures have been investigated by Bigham et al. (1990), Carlson et al. (2002), and Morin et al. (2003). The formation of such precipitates is the major process responsible for trapping arsenic by coprecipitation in the Carnoulès AMD (Morin et al., 2003), and it has also been reported as a significant process for the removal of other heavy metals in other AMD systems (e.g., Clarke et al., 1997). It has been proposed that microbes may play a significant role in this precipitation process either by catalyzing iron oxidation and/or providing nucleation sites for the precipitations of ferric hydroxysulfates (e.g., Clarke et al., 1997; Kawano and Tomita, 2001), but this latter phenomenon is less well understood. Several studies have char- acterized the diversity of microorganisms and of specific metabolic genes in AMD systems (e.g., Lopez-Archilla et al., 2004; Bruneel et al., 2006; Baker et al., 2006; Lo et al., 2007), and the spatial and temporal compositional and mineralogical variations using bulk analyses (Morin et al., 2003; Casiot et al., 2003, 2005). Other studies have developed models to identify the different abiotic and biotic actors involved in the evolution of As speciation (e.g., Lazaroff et al., 1982; Bruneel et al., 2003; Duquesne et al., 2003; Wang et al., 2007). However, only a few studies have provided chemical, mineralogical and biological data at the submicrometer spatial scale (e.g., Clarke et al., 1997; Ohnuki et al., 2004). Such data are needed to document the association of organics with minerals in AMD systems and hence to reveal how microbes impact As cycling in such settings. These data could also provide potential biosignatures within mineral precipitates that could be looked for in the geological record of AMD systems and geothermal springs (e.g., Brake et al., 2002; Phoenix et al., 2005). However, few techniques provide information at this spatial scale on both organics and mineral phases.

In this study, we have combined Scanning Transmission X-ray Microscopy (STXM), which allows imaging and acquisition of near-edge X-ray Absorption Fine Structure (NEXAFS) spectra at high spectral and spatial resolution (e.g., Bluhm et al., 2006; Yoon et al., 2006; Benzerara et al., 2007), and Transmission Electron Microscopy (TEM) to explore the variations of As speciation in association with organic polymers and bacteria at the $30 \mathrm{~nm}$ scale in samples from the Carnoulès AMD. We show that variations of As oxidation state and types of microorganisms and associated organics can be localized in heretofore unknown ways. Our observations suggest that in addition to metabolic redox transformations of As, other biological processes may play a role in the precipitation of As-Fe-rich phases in the Carnoulès AMD.

\section{EXPERIMENTAL METHODS}

\subsection{Site description and sampling}

The Carnoulès AMD, which is located on the southeastern border of the Massif central, Gard, France, has been extensively described by Leblanc et al. (1996), Morin et al. (2003) and Casiot et al. (2003). The mining activity, which stopped in 1962 at this site, resulted in about 1.5 Mt of sulfide-containing mine tailings containing $0.7 \mathrm{wt} \%$ $\mathrm{Pb}, 10 \mathrm{wt} \% \mathrm{Fe}$, and $0.2 \mathrm{wt} \%$ As. The acidic Reigous Spring (pH 2.5-4) collects meteoric waters percolating through these tailing and yields the Carnoulès AMD. Due to dilution effects, dissolved As concentrations (80-350 $\mathrm{mg} \mathrm{l}^{-1}$ ) in the AMD are anticorrelated with the flow rate of the spring $\left(0.2-1.31 \mathrm{~s}^{-1}\right)$, which varies as a function of rainfall, which, in turn, varies seasonally, with long drought periods in the summer and intense precipitation events in the spring and fall (Casiot et al., 2003).

A systematic analysis of the mineralogy of the yellow to orange $\mathrm{Fe}$ - and As-rich deposits covering the bed of the creek was performed by Morin et al. (2003) using X-ray 
absorption spectroscopy, X-ray powder diffraction, and scanning electron microscopy. Massive microbial concretions characterized by stromatolite-like laminations, at 12 and $38 \mathrm{~m}$ downstream from the acidic spring, mainly consist of nanocrystalline tooeleite, $\mathrm{Fe}_{6}\left(\mathrm{AsO}_{3}\right)_{4}\left(\mathrm{SO}_{4}\right)(\mathrm{OH})_{4}$, $4 \mathrm{H}_{2} \mathrm{O}$, a ferric arsenite hydroxysulfate mineral with a layered structure (Morin et al., 2007), mixed with minor amounts of X-ray amorphous As(III)- and As(V)-Fe(III) hydroxysulfates. The bed sediments show spatial and temporal variations and are composed mostly of tooeleite upstream (formed during the wet season), and of X-ray amorphous As(V)-Fe(III) hydroxysulfates downstream (formed during the dry season).

In this study, we focused on two samples collected in July 2005: (i) sample C12Jul05 from the microbial concretion 12 meters downstream from the spring, which contains a mixture of tooeleite and X-ray amorphous As$\mathrm{Fe}(\mathrm{III})$ hydroxysulfates, as indicated by bulk XRD analyses (see Electronic Annex), and (ii) sample S32Ju105 collected 32 meters downstream from the spring that contains primarily As(V)-Fe(III) hydroxysulfate in addition to bacteria and associated organics (see Elec- tronic Annex). For STXM and TEM analyses, one drop of a suspension collected in the Carnoulès AMD was deposited on the membrane of a lacey carbon-coated 200 mesh copper grid a few hours after sampling and airdried. STXM observations were performed less than 2 weeks after sample collection. Cell lysis likely occurred during and after drying leading to some degradation of cell internal structures; however, based on the present observations and numerous previous studies using the same sample preparation method (e.g., Benzerara et al., 2004a; Yoon et al., 2004), it can be inferred that no massive export of organics occurs over several micrometers between the preparation of the sample and its observation. Bulk XRD and SEM analyses were also conducted on the same air-dried, centrifuged solids (see Electronic Annex).

Model compounds used for interpreting As L3-edge spectra of the Carnoulès samples included crystalline tooeleite from Tooele County, Utah (Cesbron and Williams, 1992; Morin et al., 2003 and Morin et al., 2007), X-ray amorphous As(V)-Fe(III) hydroxysulfate synthesized by Thiomonas sp. (sample B1 from Morin et al., 2003), crystalline scorodite $\left(\mathrm{FeAsO}_{4} 2 \mathrm{H}_{2} \mathrm{O}\right)$, as well as commercial crystalline sodium arsenite $\left(\mathrm{AsNaO}_{2}\right)$ and sodium hydrogen arsenate $\left(\mathrm{Na}_{2} \mathrm{HAsO}_{4}\right)$.

\subsection{Scanning transmission X-ray microscopy (STXM)}

STXM observations were performed at the Advanced Light Source (ALS) (Lawrence Berkeley National Laboratory) on branch line 11.0.2.2 following the same procedures described in Yoon et al. (2004) and Bluhm et al. (2006). During our measurements, the ALS storage ring operated at $1.9 \mathrm{GeV}$ and $200-400 \mathrm{~mA}$ stored current. A $1200 \mathrm{l} / \mathrm{mm}$ grating and $40 \mathrm{Lm}$ exit slit were used for carbon imaging and spectroscopy, providing a theoretical energy resolution of $72 \mathrm{meV}$. A $1200 \mathrm{l} / \mathrm{mm}$ grating and $30 \mathrm{Lm}$ exit slit were used for iron imaging and spectroscopy, providing a theo- retical energy resolution of $160 \mathrm{meV}$. A 1200 1/mm grating and $30 \mathrm{Lm}$ exit slit were used for arsenic imaging and spectroscopy, providing a theoretical energy resolution of $400 \mathrm{meV}$. Energy calibration was accomplished using the well-resolved 3p Rydberg peak at $294.96 \mathrm{eV}$ of gaseous $\mathrm{CO}_{2}$ for the $\mathrm{C}$ K-edge, the major peak of hematite at $709.5 \mathrm{eV}$ for the $\mathrm{Fe} \mathrm{L}_{2,3}$ edges, and the second major As $\mathrm{L}_{3}-$ edge peak of scorodite at $1329.8 \mathrm{eV}$. The experimental protocols for STXM data acquisition and analysis that we used can be found in Hitchcock (2001) and Jacobsen et al. (2000). Observations were first made at the C K-edge, then at the $\mathrm{Fe} \mathrm{L}_{2,3}$-edges, then at the $\mathrm{As} \mathrm{L}_{3}$-edge. NEXAFS spectra were obtained by performing mostly line scans on reference compounds and mostly stack images for sample. Image stacks and line scans are collected by scanning the sample in $x-y$ direction (image stack) or $x$ direction (line scan) of selected sample areas at energy increments of $0.1 \mathrm{eV}$ for carbon, $0.15 \mathrm{eV}$ for iron and $0.3 \mathrm{eV}$ for arsenic over the energy range of interest $(280-310 \mathrm{eV}$ for carbon, 700-730 eV for iron and 1315-1360 eV for arsenic). Here, $x$ refers to the horizontal direction, $\mathrm{y}$ to the vertical direction, and the $x-y$ plane to the plane perpendicular to the $\mathrm{X}$ ray beam. The stack image procedure thus consists of measuring the NEXAFS spectrum for a specific element on each pixel (one pixel can be as small as $30 \mathrm{~nm}$ ) of the image. Counting times are of the order of few milliseconds or less per pixel. Normalization and background corrections of the As and Fe $\mathrm{L}_{2,3}$-edge and $\mathrm{C}$ K-edge NEXAFS spectra were performed by dividing each spectrum by a second spectrum from a Fe-, As-, or C-free location on the same sample. Enhanced contrast images were obtained by subtracting the image taken at an energy just above the absorption edge of interest from another image obtained at an energy below the absorption edge of interest.

\subsection{Transmission electron microscopy, EDXS and EELS analyses}

In addition to the drop-deposited samples observed by STXM, ultrathin sections of the same samples were prepared for TEM observations by standard diamond knife ultramicrotomy. Liquid samples collected from Carnoulès were fixed for $2 \mathrm{~h}$ in $1 \%$ glutaraldehyde at $4{ }^{\circ} \mathrm{C}$, centrifuged $(6500 \mathrm{rpm})$, rinsed three times in a $0.1 \mathrm{M}$ acetic acid buffer ( $\mathrm{pH} 4.4)$ and left in the last rinsing solution for $18 \mathrm{~h}$ at $4{ }^{\circ} \mathrm{C}$, then dehydrated (ethanol and propylene oxide) before embedding in an Epon resin (Epon 812). The fixation step limits lysis of cell structures. Ultrathin sections (70-nm thick) were cut with a LEICA ultramicrotome (Ultracut E). Thin sections were not stained. Because of the potential modifications of the mineralogy resulting from this treatment, we characterized the minerals only in the drop-deposited samples. It can be noted, however, that no significant difference was detected on the ultramicrotomy and the drop-deposited samples (e.g., Fig. 6A and $\mathrm{C}$ ).

TEM observations were carried out on a JEOL $2100 \mathrm{~F}$ microscope operating at $200 \mathrm{kV}$, equipped with a field emission gun, a high resolution UHR pole piece, and a Gatan energy filter (GIF 200). Energy dispersive X-ray spectrom- 
etry (EDXS) analyses were performed using a JEOL detector with an ultrathin window that allowed detection of low$\mathrm{Z}$ elements. The dwell time was optimized to acquire sufficient signal intensity and to limit beam damage.

\section{RESULTS}

3.1. Analysis of As speciation and mineralogy in Carnoulès samples at the nanoscale

Fig. 1 shows the As L3-edge NEXAFS spectra of reference mineral phases containing either arsenite, $\mathrm{As}(\mathrm{III}) \mathrm{O}_{3}{ }^{3-}$, or arsenate, $\mathrm{As}(\mathrm{V}) \mathrm{O}_{4}{ }^{3-}$. The energy position of the second peak in the $\mathrm{L}_{3}$-edge of scorodite was arbitrarily fixed at $1329.8 \mathrm{eV}$ and was used as an energy calibration standard. The As $\mathrm{L}_{3}$-edge spectra of As(III)-containing solids show a single peak at $1326.2 \mathrm{eV}$, while an additional peak at $1329.8 \mathrm{eV}$ can be observed for As(V)-containing phases. As L2,3-edge spectra were acquired consecutively as a function of time on the same area, and no changes in the spectra were detected with increasing spectral acquisition time, indicating the absence of X-ray beam-induced oxidation or reduction during data acquisition. The XANES spectra at the $\mathrm{L}_{3}$-edge are thus sensitive to the redox state of As, and no significant difference were observed among the arsenite-containing reference compounds or among those containing arsenate. Based on the spectroscopic differences between arsenite- and arsenate-bearing compounds, their spatial distribution could be assessed by energy-filtered imaging at a spatial resolution of less than $100 \mathrm{~nm}$ in Carnoulès samples.

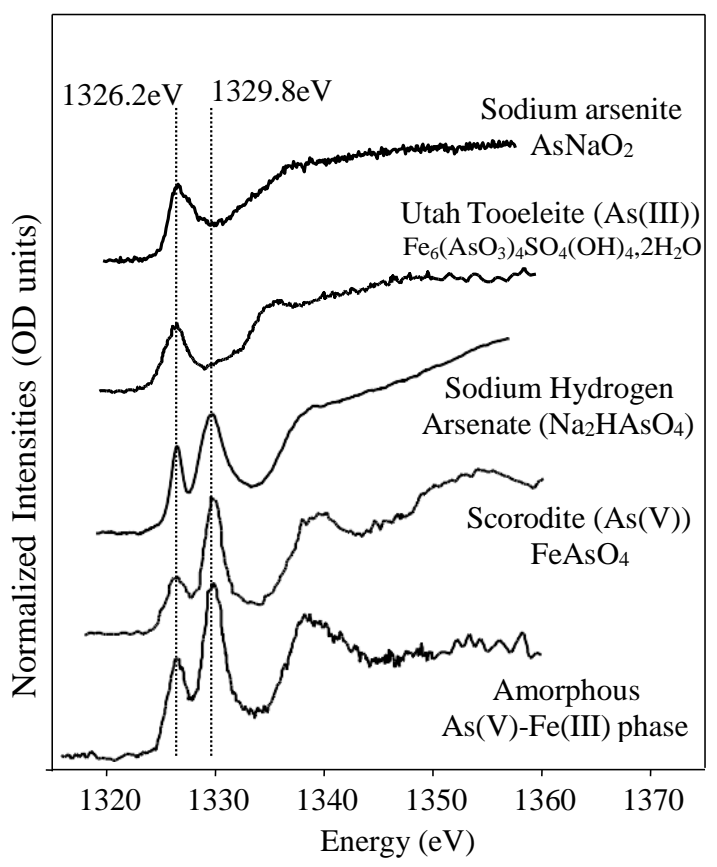

Fig. 1. NEXAFS spectra of As(III)- and As(V)-containing reference compounds at the As- $\mathrm{L}_{3}$ edge. Dashed lines indicate energy positions at around 1326.2 and $1329.8 \mathrm{eV}$, which are maximum absorption peaks of $\mathrm{As}(\mathrm{V})$.
Fig. 2 shows the image of a cluster of mineral particles in sample C12Jul05 taken at an energy below the As L3-edge $(1320 \mathrm{eV})$. By taking STXM images at different energies (i.e., below the As L3-edge at $1320 \mathrm{eV}$, at $1326.8 \mathrm{eV}$ (absorption peak for both arsenite and arsenate) and at $1329.8 \mathrm{eV}$ (absorption peak for arsenate only) and measuring the variations in X-ray absorption at these different energies, it was possible to infer the spatial distribution of total arsenic, arsenite, and arsenate in this cluster (Fig. 2). NEXAFS spectra measured at the As $\mathrm{L}_{3}$-edge confirmed that most of the cluster is composed of an As(III)-containing phase while a small portion of the sample located on the bottom left of Fig. 2 is composed of an $\mathrm{As}(\mathrm{V})$-containing phase (Fig. 2E). NEXAFS spectra were extracted from stack images obtained on the same cluster at the $\mathrm{Fe} \mathrm{L}_{2,3}$ edges and showed that the two different areas contain only Fe(III) (Fig. 2F). The same cluster was located and analyzed by TEM (Fig. 2G), which provided complementary information with higher spatial resolution images, multielemental analyses by EDXS, and crystallographic information by electron diffraction. The As(III)-rich area detected by STXM is composed of very fine-grained, platy crystalline phases containing $\mathrm{As}, \mathrm{S}$, and $\mathrm{Fe}$ and showing lattice spacings at $3.2 \AA$ (Fig. $2 \mathrm{H}$ ). These phases where highly sensitive to the electron beam and the acquisition of electron diffraction patterns required very low electron doses in order to prevent them from becoming amorphous almost instantaneously. All of these observations, taken together, are consistent with this phase being tooeleite, a layered mineral identified in nanocrystalline form in the Carnoulès AMD by Morin et al. (2003, 2007). The As(V)-rich area detected by STXM (Figs. 2 and 3 ) is composed of clusters of 100-200 nm particles which are amorphous by electron diffraction and contain Fe, S, and As (Fig. 2I). These mineral phases are similar in morphology, chemical composition, and As redox state to the $\mathrm{As}(\mathrm{V})-\mathrm{Fe}(\mathrm{III})$ hydroxysulfates from the Carnoulès AMD described by Morin et al. (2003). The same analyses were performed on mineral clusters from sampleS32Jul05 (Fig. 3). Consistently with bulk analyses (see Electronic Annex), only Fe(III)-As(V)-containing phases were detected in this sample using STXM energy-filtered imaging.

\subsection{Localization of microorganisms in Carnoulès AMD samples}

The same samples were also imaged by STXM at the C K-edge. Microorganisms can be localized using the absorption of characteristic carbon functional groups (peptides) in proteins at $288.2 \mathrm{eV}$, which is the most prominent absorption feature in the NEXAFS spectrum of microorganisms at the C K-edge (e.g., Benzerara et al., 2006). Peptide-bond maps were obtained on both Carnoulès AMD samples, which showed two morphotypes, a long rods up to $4 \mathrm{Lm}$ in length and $0.2 \mathrm{Lm}$ in width and shorter rods around $2 \mathrm{Lm}$ in length and $0.5 \mathrm{Lm}$ in width (Figs. 4-6). NEXAFS spectra were systematically acquired at the $\mathrm{C}$ K-edge on these microorganisms (Figs. 4 and 5C) and were similar to the spectra from reference bacteria and archeal cells (Benzer- 

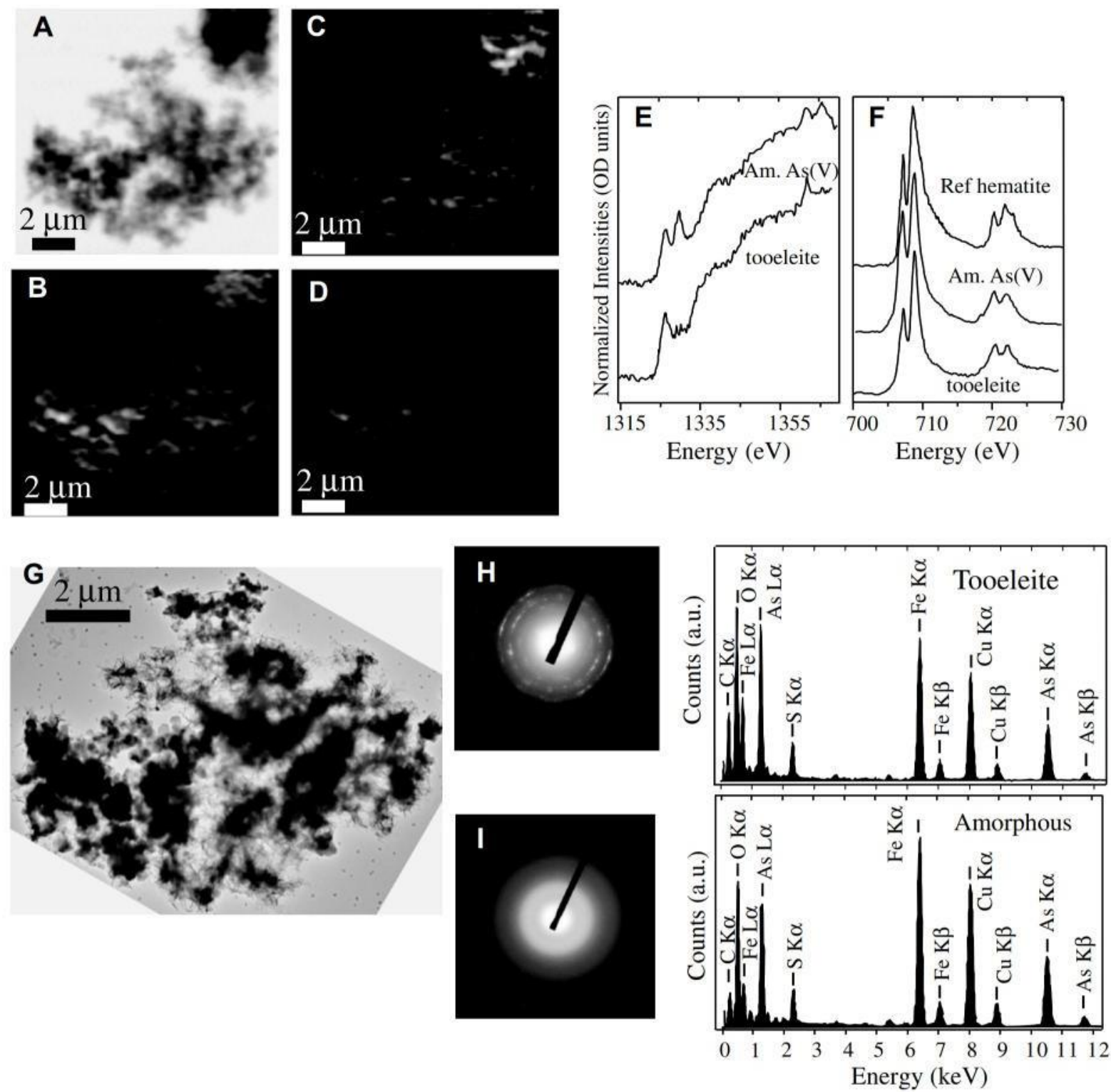

Fig. 2. STXM and TEM analyses of mineral phases in sample C12Jul05. (A) STXM image below the As edge (1320 eV). (B) STXM map of arsenic. (C) STXM map of As(III)-containing phases (tooeleite). (D) STXM map of As(V)-containing phases. (E) NEXAFS spectra of the $\mathrm{As}(\mathrm{III})$ - and $\mathrm{As}(\mathrm{V})$-containing phases (respectively, tooeleite and $\mathrm{Am} \mathrm{As}(\mathrm{V})$ ) at the $\mathrm{As} \mathrm{L}_{2,3}$-edges. (F) NEXAFS spectra of the As(III)- and $\mathrm{As}(\mathrm{V})$-containing phases (respectively, tooeleite and Amorphous- $\mathrm{Am} \mathrm{As}(\mathrm{V})$ ) and of reference hematite at the $\mathrm{Fe} \mathrm{L}_{2,3}$-edges. (G) TEM image of the same area $(\mathrm{H})$ Electron diffraction pattern and EDX analysis on As(III)-containing tooeleite. (I) Electron diffraction pattern and EDX analysis on the $\mathrm{As}(\mathrm{V})$-containing amorphous phase. Distances at 3.2, 2.6, 2,2 and 1.7 $\AA$ are all consistent with tooeleite structure (see Electronic Annex).

ara et al., 2004a). In addition to a major peak at $288.2 \mathrm{eV}$, both samples showed narrow peaks at 285.1 , 286.6 , and $289.3 \mathrm{eV}$, which have been interpreted previously as arising from aromatic groups, phenolic or ketonic groups, and carbonyl or alcohol groups, respectively (Fig. 5C). On one microbial filament, which had a lower protein content as shown on the peptide map (Fig. 5B, microorganism labeled b), we observed an additional narrow peak at $290.7 \mathrm{eV}$. The assignment of this peak to a particular C-functional group is more problematic Its narrow width suggests that it corresponds to a $1 \mathrm{~s}-\pi$ electronic transition, and the energy position of this peak is consistent with $1 \mathrm{~s}-\pi$ electron transitions in carbonate, possibly in carbonyl functional groups (Schumacher et al., 2005), although at slightly higher energy than is commonly observed.

To investigate their elemental composition and their association with mineral phases at the $30-\mathrm{nm}$ scale, the same microbial cells were systematically located and imaged by TEM (Figs. 4 and 5F). Some cells were hardly visible by TEM when highly encrusted by As-rich mineral phases. EDXS analyses were performed on cell areas 

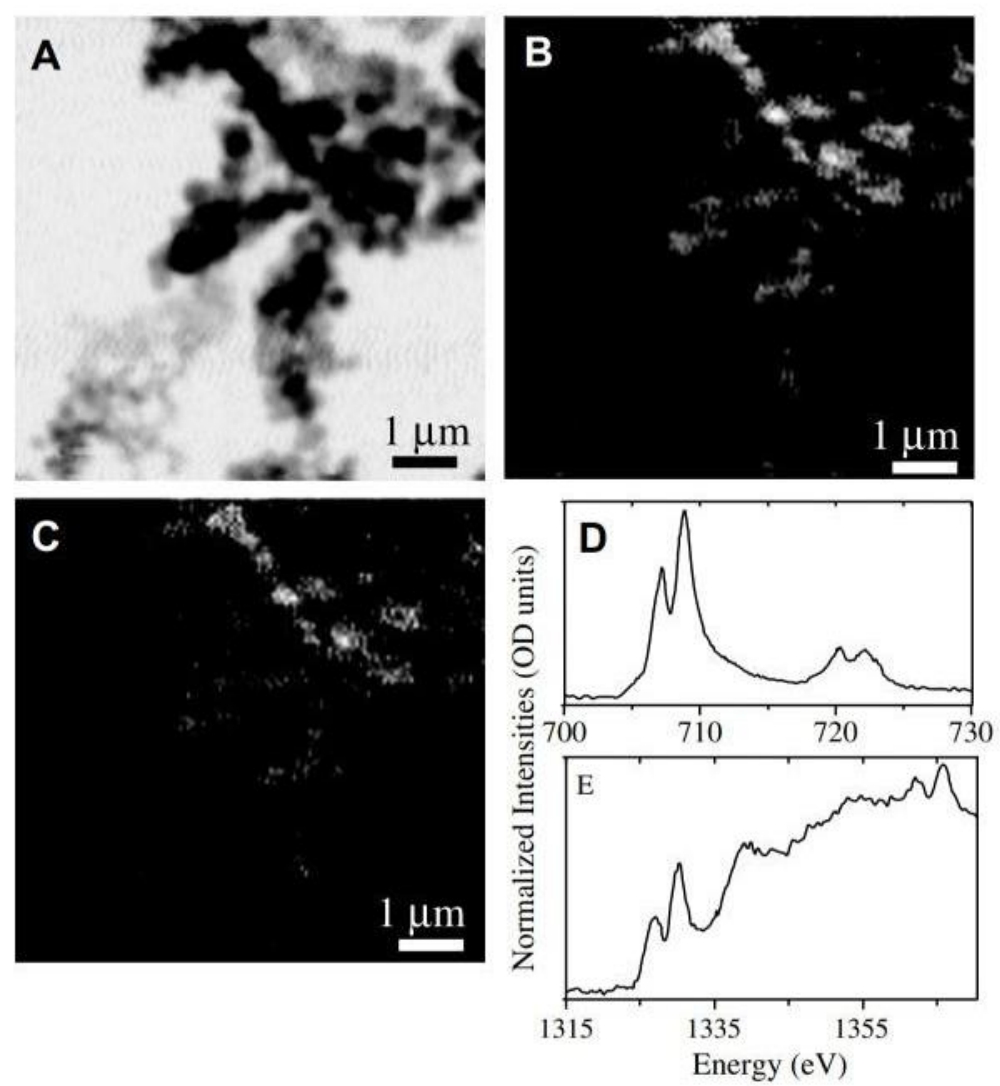

Fig. 3. STXM analysis of mineral phases in sample S32Jul05. (A) STXM image below the As edge (1320 eV). (B) STXM map of arsenic. (C) STXM map of $\mathrm{As}(\mathrm{V})$-containing phases. (D) NEXAFS spectra of the globular phases observed on image (A) at the $\mathrm{Fe} \mathrm{L}_{2,3}$-edges. (E) NEXAFS spectra of phases observed on image (A) at the As $\mathrm{L}_{2,3}$-edges.

where, to the extent possible, no mineral phase was detected. The resulting spectra showed enrichment in $\mathrm{C}$ and $\mathrm{P}$ compared to the surrounding mineral phases. In addition, they qualitatively showed various Fe:S:As ratios as suggested by heights of the respective $\mathrm{K} \alpha$ peaks for these elements. It was, however, impossible to determine whether the $\mathrm{Fe}, \mathrm{S}$, and As X-ray emission peaks come from within the cells or from mineral phases attached to the cell surface.

Thin sections prepared by ultramicrotomy were also examined by TEM to further document the association of mineral phases with the cell walls of microorganisms in the Carnoulès AMD samples. Several cell sections completely mineralized by $\mathrm{Fe}$ - and As-containing mineral phases were observed (Fig. 6). A variety of patterns were observed, some showing a mineral layer distributed around single cells with an irregular thickness $(>200 \mathrm{~nm}$ on average). In other cases, however, the mineral layer had a relatively constant thickness of $40-50 \mathrm{~nm}$. Mineralized protuberances between 100 and $200 \mathrm{~nm}$ in size bulging from the cell walls were observed in many sections (Fig. 6A and B).

\subsection{Detection of organic carbon in Carnoulès samples}

In addition to microbial cells which appeared as bright, localized areas on protein maps, we observed a second, more widely distributed type of organic component in samples S32Jul05 and C12Jul05 that is systematically associated with $\mathrm{Fe}-\mathrm{As}$-containing mineral phases (Fig. 7).

NEXAFS spectra measured at the $\mathrm{C}$ K-edge on the $\mathrm{Fe}-$ As-containing mineral clusters were different from those measured on microbial cells. Although C K-edge NEXAFS spectra from the $\mathrm{Fe}-\mathrm{As}$-containing mineral clusters showed no peptide bonds $(288.2 \mathrm{eV})$, peaks at $284.4,287.6,288.5$, and $290.7 \mathrm{eV}$ were detected (Fig. 7C). None of these peaks can be attributed to chemical elements contained by tooeleite or by amorphous $\mathrm{Fe}(\mathrm{III})-\mathrm{As}(\mathrm{V})$ hydroxysulfates and therefore are attributed to various carbon functional groups comprising organic carbon, possibly polymers, attached to these As-Fe-containing phases. The peak at $284.4 \mathrm{eV}$ corresponds to functional groups with unusually low energy $\pi *$ states, likely quinones (e.g., Haberstroh et al., 2006); the peak at $287.6 \mathrm{eV}$ can be attributed to either aliphatic-C and/or aromatic carbonyl; the peak at $288.5 \mathrm{eV}$ is characteristic of carboxylic groups, and finally the peak at $290.7 \mathrm{eV}$ is similar to the one also obtained from a heavily encrusted microbial cell. Such organics were observed to be intimately associated with the Fe-As-S-containing mineral clusters at a spatial scale down to a few tens of nanometers. Although a precise detection limit is difficult to assess, it can be inferred from the data that, if present, proteinaceous material is very minor in those organic polymers. 

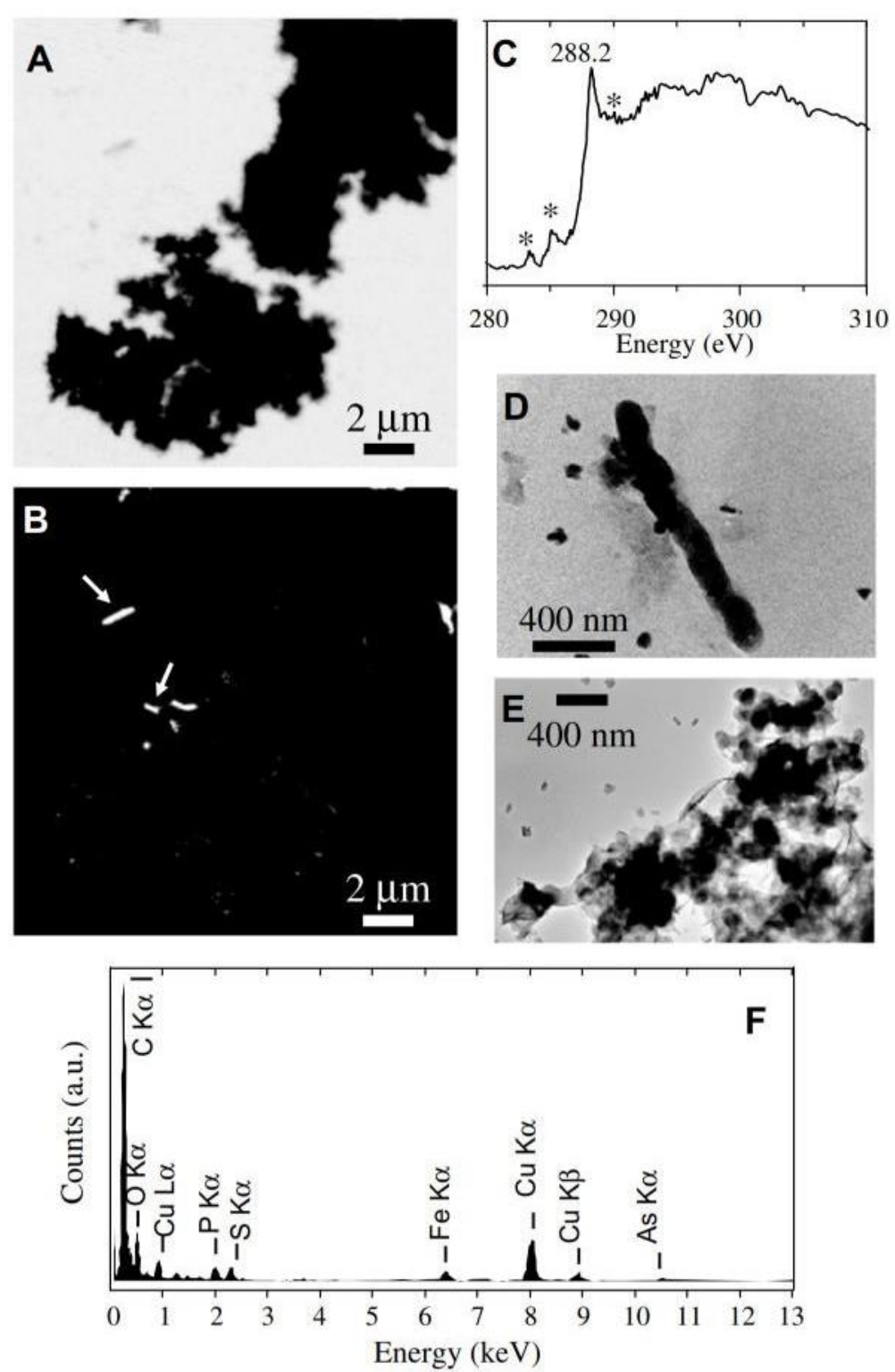

Fig. 4. STXM and TEM observations of microorganisms in sample C12Jul05 (same area as in Fig. 2). (A) STXM image below the C K-edge $(280 \mathrm{eV})$. (B) STXM map of organic carbon absorbing at $288.2 \mathrm{eV}$ (mostly proteins). (C) NEXAFS spectrum at the C K-edge of a microorganism imaged on (B) (upper left). Stars indicate the position of peaks at 285.1, 286.6, and $289.3 \mathrm{eV}$. (D) TEM image of the microorganism on the upper left on (B) - see arrow. (E) TEM image of the microorganism in the middle of (B) - see arrow. This microorganism is covered by $\mathrm{As}(\mathrm{III})$ - and $\mathrm{As}(\mathrm{V})$ containing precipitates. $(\mathrm{F})$ EDXS analysis on the microorganism shown in (D).

\subsection{Detection of mineralized vesicles in Carnoulès samples}

Most of the mineral precipitates in S32Jul05 appear as clusters of electron dense spheres with sizes ranging from 100 to $200 \mathrm{~nm}$. However, we observed clusters of more transparent globules in the same size range by both STXM and TEM (Fig. 8A). STXM observations showed that these globules contain carbon with C K-edge NEXAFS spectra that were different from those obtained on microbial cells and on the pervasive organics associated with the dense mineral precipitates (Fig. 8B). These spectra have peaks at 285.1 and $288.6 \mathrm{eV}$ which can be attributed to $1 \mathrm{~s} \rightarrow \pi *$ electronic transitions in aromatic and carboxylic functional groups, respectively, and one peak at $289.6 \mathrm{eV}$ that is classically interpreted as either $1 \mathrm{~s} \rightarrow \pi *$ electronic transitions in carbonyl groups or $1 \mathrm{~s} \rightarrow \sigma *$ transitions in aliphatic $\mathrm{C}-\mathrm{OH}$ groups. At higher magnification, these globules show a central lumen and a nearly 20-nm thick wall suggesting that they are vesicles (Fig. 8C). These vesicles were observed by TEM in thin sections, confirming that they consist of a mineralized wall surrounding an electron-transparent inner core (Fig. 8D and E). The mineralized walls contain $\mathrm{Fe}$, As, and $\mathrm{S}$ as shown by EDXS analyses on both bulk and thin section samples (Fig. 8F). 

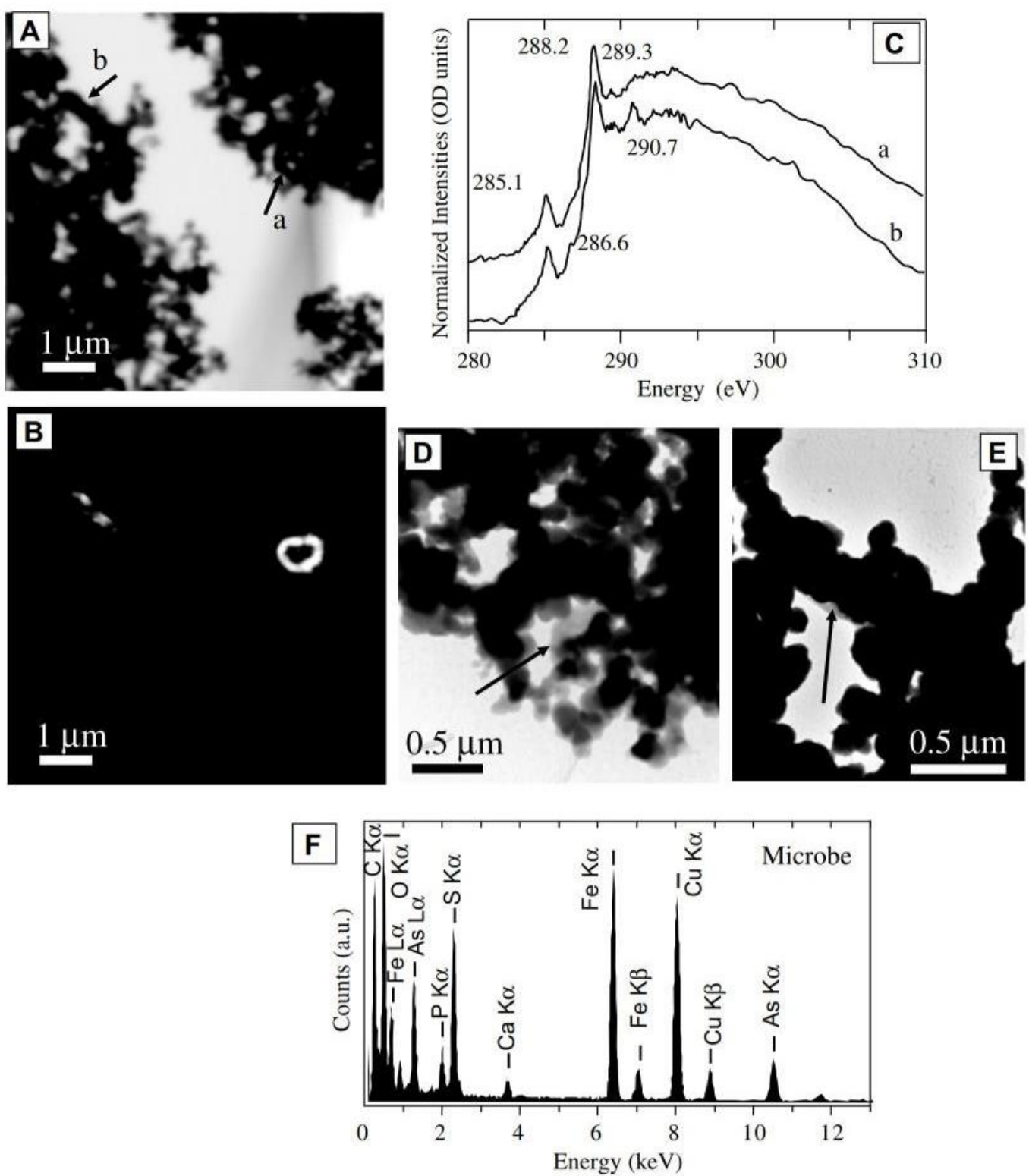

Fig. 5. STXM and TEM analysis of microorganisms in sample S32Jul05. (A) STXM image at $288.2 \mathrm{eV}$ (maximum absorption peak of amide groups). (B) STXM map of organic carbon absorbing at $288.2 \mathrm{eV}$ (mostly proteins). Two microorganisms can be observed. (C) NEXAFS spectra at the $\mathrm{C}$ K-edge of the two microorganisms observed on image (A), labeled $a$ and $b$. (D) and (E) TEM images of the two microorganisms noted, respectively, $\mathrm{a}$ and $\mathrm{b}$ on image (A). Arrows show a lower density area attributed to a portion of the microorganisms that is not covered by the dense As-rich hydroxysulfate precipitates. (F) EDXS analysis obtained from a portion of the microorganism noted $a$ that is not covered apparently by precipitates.

\section{DISCUSSION}

\subsection{Spectroscopy at the As $L_{3}$ edge}

Only a few studies have investigated both the organic and mineral fractions in AMD samples at the submicrometer-scale because of the difficulty of characterizing both at the same time. Ohnuki et al. (2004), for example, combined scanning-particle-induced X-ray emission analyses with TEM and epifluorescence microscopy to document the mineralogy and associations between microorganisms and mineral phases in a biomat from discharged arsenic mine water; however, they used bulk XANES spectroscopy measurements to obtain information on the speciation of As and Fe. STXM observations provide an interesting way to combine this information in a single analysis. Studies of As speciation by X-ray absorption spectroscopy techniques are usually performed at the K-edge around $11,872 \pm 3 \mathrm{eV}$ (e.g., Morin et al., 2003; Cances et al., 2005; Thoral et al., 2005; Polizzotto et al., 2006). However, studies of As-containing materials at the $\mathrm{As} \mathrm{L}_{2,3}$-edge $(\sim 1330 \mathrm{eV})$ are possible but rare (e.g., Akabayov et al., 2005). Here we show that this edge provides unambiguous information on As redox state in the Carnoulès AMD samples. In addition, using 

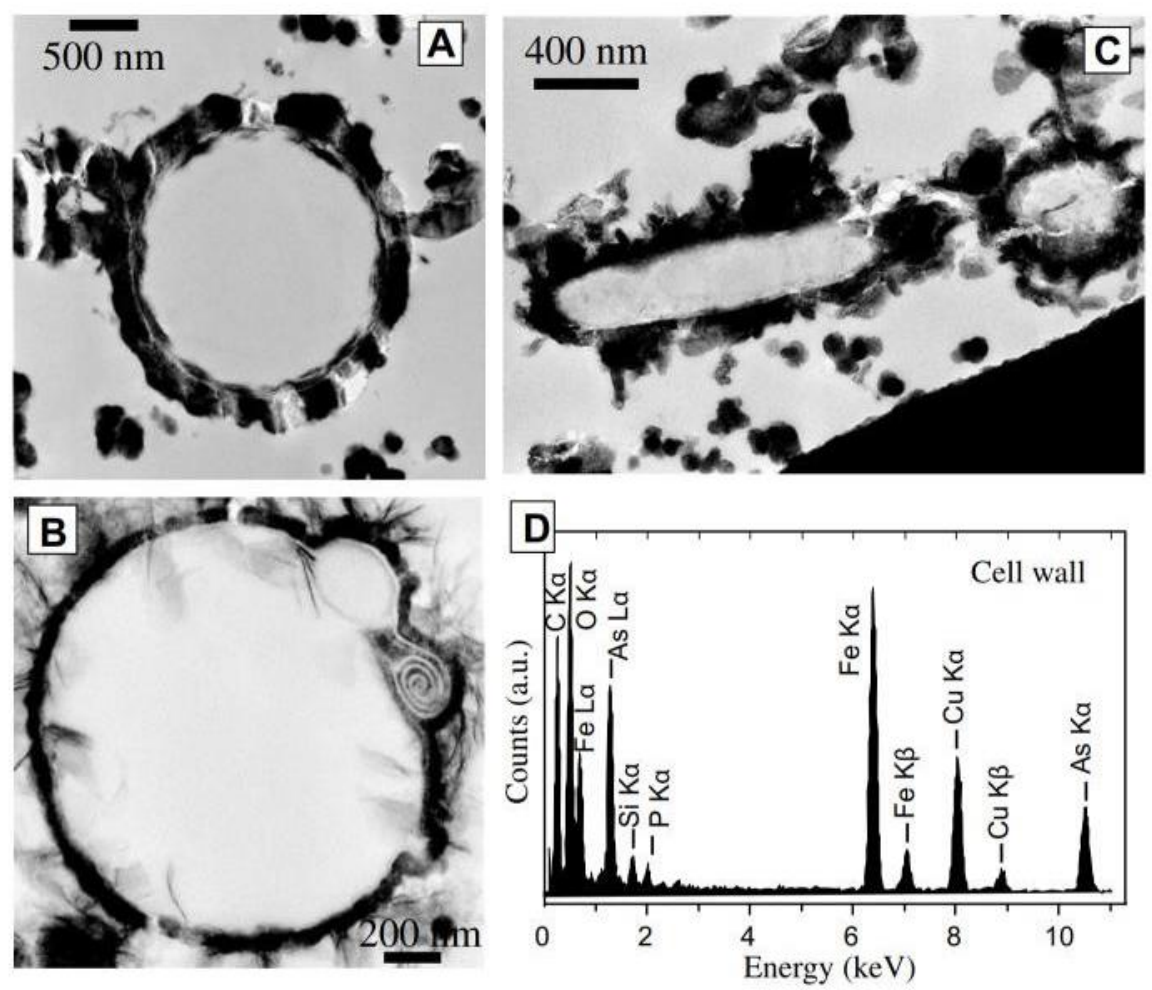

Fig. 6. TEM analysis of ultramicrotomy thin sections in Carnoulès samples. (A-C) TEM images of sections in microbial cells showing different kind of encrustations: with two different layers, a layered inner one concentric with a massive outer one (A), a thin layer of constant thickness and bulges (B), a layer of varying thickness around the cells (C). (D) EDXS analysis obtained from the outer cell wall observed in (A).
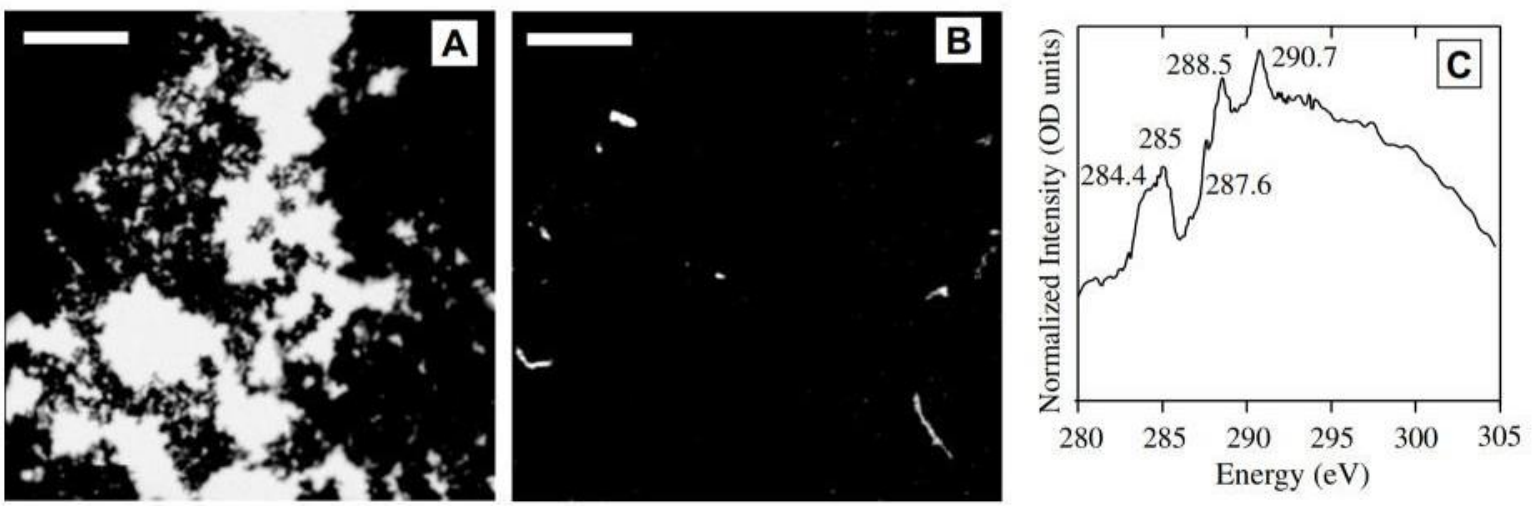

Fig. 7. STXM and TEM analysis of organics in sample S32Jul05. (A) STXM image at $288.6 \mathrm{eV}$ (maximum absorption peak of carboxylic groups). Scale bar is $5 \mu \mathrm{m}$. (B) STXM map of organic carbon absorbing at $288.6 \mathrm{eV}$. Six hot spots corresponding to microbial cells can be observed. In addition a faint signal is also observed pervasively in association with the precipitates on the rest of the map. Scale bar is $5 \mu \mathrm{m}$. (C) NEXAFS spectrum at the C K-edge of the pervasive organics associated with the precipitates.

STXM energy-filtered imaging capabilities, it is possible to map different phases with different As redox states at a spatial resolution below $100 \mathrm{~nm}$. Measurement of NEXAFS spectra at the As $\mathrm{L}_{3}$-edge using STXM has been possible to date only on beamline 11.0.2.2 at the Advanced Light Source (Berkeley), although such measurements are now possible on the STXM beamline at the Canadian Light Source in Saskatoon, Saskatechewan, and will soon be possible at Bessy II in Berlin, Germany.
Both solid phases in the two Carnoulès samples are in the $10-200 \mathrm{~nm}$ size range, but As(III)-containing tooeleite appears as thin sheets while the $\mathrm{As}(\mathrm{V})-\mathrm{Fe}(\mathrm{III})$ hydroxysulfates appears as globules that are amorphous in electron diffraction. Although nanocrystalline tooeleite has only been described in the Carnoulès AMD system, As(V)$\mathrm{Fe}(\mathrm{III})$-containing amorphous phases with various sizes and morphologies have been observed in other AMD systems (e.g., Kawano and Tomita, 2001; Carlson et al., 

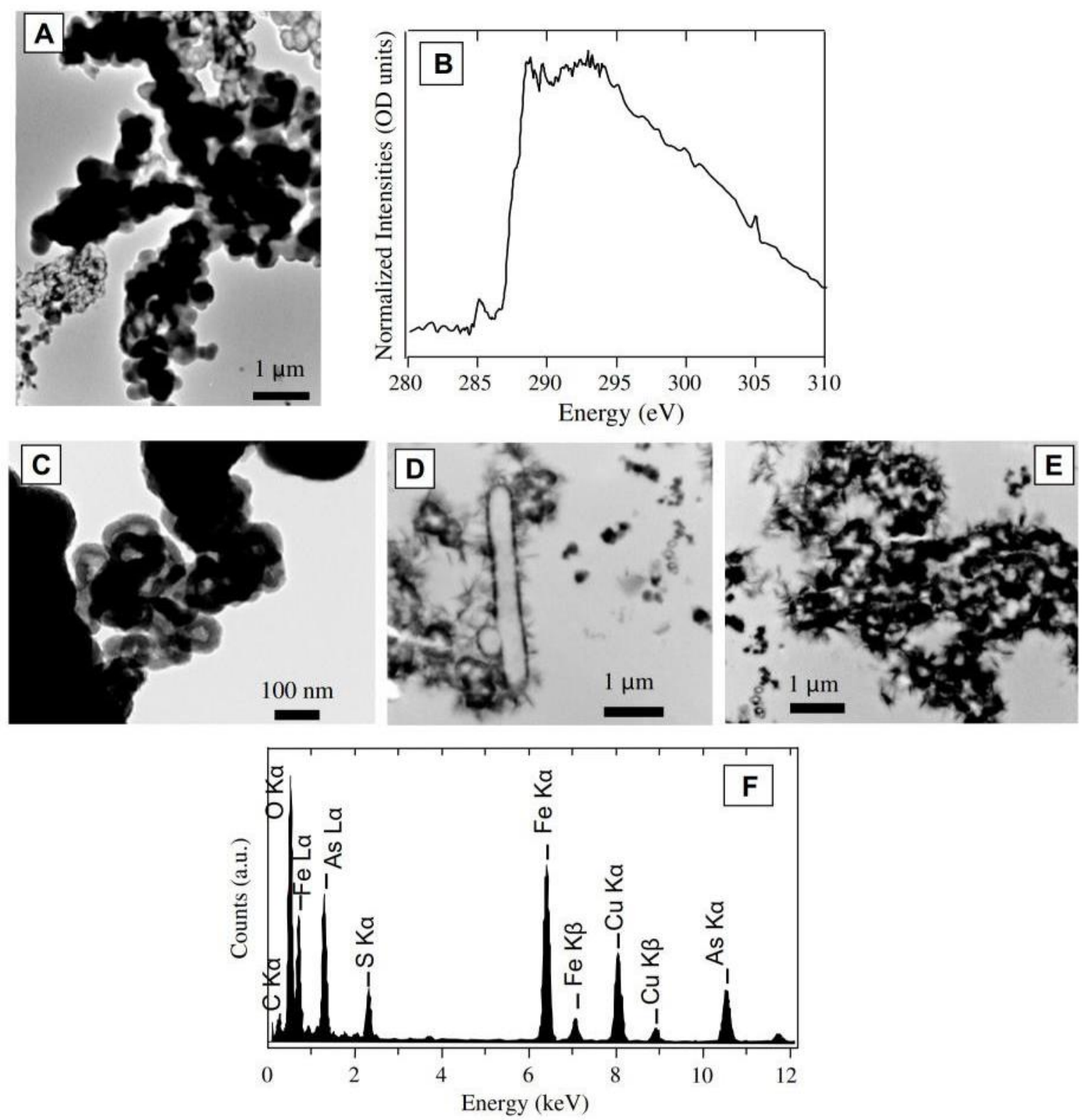

Fig. 8. TEM analysis of mineralized vesicles in Carnoulès samples. (A) TEM image of the same area imaged by STXM and shown in Fig. 3. Note the difference between spheres very dense to electrons (in the center) and those more transparent (e.g., on the bottom left hand corner). (B) STXM spectrum at the C K-edge on the vesicles. (C) TEM images of a cluster of vesicles at higher magnification (deposited drop). The thick electron dense wall is visible on this picture. (D and E) TEM images of the vesicles observed on ultramicrotomy sections of the Carnoulès samples. Note that some are associated closely with bacterial cells (D). (F) EDXS analysis of the electron dense wall of a vesicle.

2002). They consist of poorly ordered $\mathrm{As}(\mathrm{V})-\mathrm{Fe}(\mathrm{III})-$ hydroxysulfates, with $\mathrm{As} / \mathrm{Fe}$ ratios as high as 0.8 , which form instead of schwertmannite in As- and sulfate-rich waters (e.g., Carlson et al., 2002; Morin et al., 2003). This specific mineralogy, consisting in As(III)-tooeleite and amorphous $\mathrm{As}(\mathrm{V})$ hydroxysulfates, which both exhibit As/Fe molar ratio within $0.6-0.8$ range, is likely related to very high dissolved $\mathrm{As}$ (III) concentrations in the Carnoulès AMD, up to $250 \mathrm{mg} \mathrm{l}^{-1}$. This contrasts with other AMDs, where As(III) and As(V) sorbed on schwertmannite, and $\mathrm{As}(\mathrm{V})$-jarosite are generally dominant (see e.g., Morin and Calas, 2006 and references therein).

\subsection{Role of microorganisms in the precipitation of As phases at the Carnoulès AMD site}

Previous field observations and laboratory studies, conducted with isolated indigenous bacterial strains from the Carnoulès AMD system, suggest that the As(III)- and $\mathrm{As}(\mathrm{V})$-containing mineral phases form via distinct mechanisms: oxidation of $\mathrm{Fe}(\mathrm{II})$ without $\mathrm{As}$ (III) oxidation, for example, by Acidithiobacillus ferrooxidans strains, leads to the formation of tooeleite (Duquesne et al., 2003), while oxidation of both $\mathrm{Fe}(\mathrm{II})$ and $\mathrm{As}(\mathrm{III})$, for example, by Thiomonas sp. strains, leads to the formation of $\mathrm{As}(\mathrm{V})-\mathrm{Fe}(\mathrm{III})$ 
hydroxysulfates (Casiot et al., 2003; Morin et al., 2003). This latter mechanism is thought to dominate downstream in the dry season and can explain the unique mineralogical composition of Carnoulès sample S32Jul05, which consists predominantly of $\mathrm{As}(\mathrm{V})-\mathrm{Fe}(\mathrm{III})$ hydroxysulfates. In contrast, the former mechanism is thought to dominate in the formation of the massive stromatolite-like concretions, which mainly consist of tooeleite (sample C12Ju105). In this study, the intimate association of minor amounts of $\mathrm{As}(\mathrm{V})-$ $\mathrm{Fe}$ (III) hydroxysulfates with tooeleite in this sample suggests either the coexistence of various metabolic activities, or of particulate transport and aggregation, following the formation of these phases. In such complex assemblages, simultaneous observation of microorganisms and minerals on the submicron scale may help in better localizing where the biomineralization processes occur. However, the detection of microorganisms is usually difficult in highly mineralized samples as shown by various attempts to do so by TEM studies (e.g., Benzerara et al., 2006). In contrast, STXM spectromicroscopy allows the detection of living and/or fossilized microorganisms by characterizing and mapping, within a mineral matrix, organic functional groups comprising microbial cells (see, e.g., Benzerara et al., 2004a and Benzerara et al., 2006). This approach allows one to study whether there is a selective mineralization of microorganisms by specific mineral phases in the Carnoulès AMD as was proposed by Jones and Renaut (2007) in the Waiotapu geothermal springs (New Zealand). Such selective biomineralization was not observed in the Carnoulès AMD system as microorganisms were found to be intimately associated with both in the tooeleite and the As(V)$\mathrm{Fe}$ (III) hydrosulfate clusters. However, no inference on the identities of the microbial species can be made using NEXAFS spectra and only the observed morphologies can provide inconclusive hints. Although sequences similar to Gallionella ferruginea were dominant in the $16 \mathrm{~S}$ rDNA libraries obtained by Bruneel et al. (2006) from bacterial samples collected from the Carnoulès AMD system, no stalk-like compounds that are commonly observed in Gallionella-rich environments, were observed (e.g., Chan et al., 2004; Hallberg and Ferris, 2004). Although epifluorescent microscopy and fluorescent in situ hybridization (FISH) are powerful tools to locate specific microbial taxons in AMD samples at the micrometer-scale (e.g., Lopez-Archilla et al., 2004; Bouchez et al., 2006), these techniques are limited regarding the achieved spatial resolution and the chemical information provided about associated mineral phases. However, a combination of epifluorescent microscopy, STXM, and TEM on the same samples (e.g., Lawrence et al., 2003) would provide the necessary information on the structure and composition of mineral-biofilm assemblages to infer correlations between specific microbial groups and mineral phases comprising the Carnoulès AMD system.

Studying the biomineralization patterns of microorganisms in the Carnoulès AMD system is of interest because such patterns can help in determining if they can serve as nucleation sites for the formation of As-rich phases and if the biominerals exhibit unique textures that could be looked for in the fossil record of acidic As-rich environ- ments (e.g., Brake et al., 2002; Baker and Banfield, 2003). Some previous studies have investigated the role of microorganisms in the precipitation of hydroxysulfates in both acid mine drainage (Clarke et al., 1997) and hydrothermal environments (Inskeep et al., 2004). Clarke et al. (1997) investigated the precipitation of Zn-rich ferric hydroxysulfates on microorganisms in AMD lagoon sediments. They observed precipitates within the polysaccharide-rich capsule surrounding the bacteria and on the outer cell walls and concluded that bacteria facilitated mineral precipitation. In Beowulf Spring at Yellowstone National Park, Inskeep et al. (2004) showed that most of the iron-arsenic hydroxysulfate precipitates in the sediments they collected were associated with microbial filaments reminiscent of some $\mathrm{Fe}$ oxidizing bacteria that produce sheaths. Interestingly, Foster and Ashley (2002) showed that different types of mats dominated by cyanobacteria or by Leptothrix, seques- ter arsenic in different ways by sorption on polysaccharides or Fe-oxyhydroxides, respectively. In the Carnoulès AMD system, however, we have shown that microbes are frequently encrusted by minerals but that most of the $\mathrm{Fe}-\mathrm{As}$ containing precipitates were not directly associated with microbial cells. Culture- and molecular-based analyses of the microbial diversity of the Carnoulès AMD system as well as mineral precipitation experiments using microcosms suggest that microorganisms play a major role in the formation of these phases but that they are not the major nucleation sites (Casiot et al., 2003; Morin et al., 2003).

It is interesting to consider the diversity of the biomineralisation patterns that can be observed in thin sections and to compare them with observations made by Inskeep et al. (2004). Similar to what this earlier study reported for samples from Yellowstone National Park, we observed in the Carnoulès AMD samples many cross- and longitudinal sections of cells showing isolated spheres of $\mathrm{Fe}-\mathrm{As}-\mathrm{S}$-rich precipitates agglomerating outside the cell wall and forming, in some cases, thick continuous layers around the cells (Fig. 6C). In addition to these biomineralization patterns, we sometimes observed cells surrounded by a texturally more homogeneous mineralized crown of nearly constant thickness of around $50 \mathrm{~nm}$ (Fig. 6B). Such biomineralization patterns can be compared tentatively with those observed by Benzerara et al. (2004b) for an experimentally calcified Gram-negative bacterium in which calcium phosphates had precipitated within the periplasm, forming a crown of nearly constant thickness of around $30 \mathrm{~nm}$. The biological processes responsible for the precipitation of calcium phosphates within the periplasm of some Gram-negative bacteria are not yet understood; however, the similar chemical behavior of arsenate compared to phosphate suggests that similar mechanisms might be involved. Alternatively, all the precipitates that are observed may be extracellular and differences may relate to variations in the cell wall chemistry of different microorganisms. Moreover, on some cells, bulges of the mineralized crowns were frequently observed (Fig. 6). Those might be reminiscent of similar bulges observed by Obst et al. (2006) for calcifying cyanobacterial cells and by Baker et al. (2006) for bacterial consortia from AMD systems. The observed variations of different biomineralization patterns might be related either 
to different growth stages of the same species or to differences in the biomineralization processes between different species. Finally, some features were observed on the mineralized cells for which we do not know an analog or origin, such as the electron dense twirled pattern observed in one of the bulges of a cross-section of a cell shown in Fig. 6B, or the two-layer pattern in Fig. 6A with one massive external layer lying on a thin fibrous internal layer. These obser-

vations demonstrate that very fine ultrastructural details can be fossilized in such As-rich environments similar to the ordered mosaics of proteins called S-layers that Phoenix et al. (2005) observed in Waiotapu hot springs (New Zealand). Experimental biomineralization of different strains isolated from the Carnoulès AMD system would be interesting to perform in order to further investigate this issue.

While some previous studies have stressed the ability of microorganisms to favor mineral precipitation (e.g., Clarke et al., 1997; Jones and Renaut, 2007), we observe in the Carnoulès samples that some precipitates are not associated with microbial cells (e.g., Fig. 7). Those are, however, associated with other organic compounds that might have a significant impact on their formation or subsequent behavior. Although the association of pervasive organics associated with the $\mathrm{As}(\mathrm{V})-\mathrm{Fe}(\mathrm{III})$-containing nanophases has not been observed prior to the present study, intimate intergrowths of polysaccharides and submicrometer-sized aragonite

spheres have been detected in carbonate microbialites (e.g., Benzerara et al., 2006; Dupraz and Visscher, 2005). Whether these organic polymers have an origin exogenous to the Carnoulès AMD system or are produced by the numerous indigenous autotrophic microbes found at Carnoulès cannot be determined from our spectroscopic data, which reveal only the main carbon functional groups comprising them. Identification of these organics by bulk organic geochemistry analyses, including mass spectrometry on purified fractions may help to better understand their origin. Chan et al. (2004) demonstrated that microbially derived organic polymers can provide nucleation sites in AMD systems and can lead to the formation of mineral phases that do not form away from these polymers. We suggest that organics in the Carnoulès AMD system might im-

pact the nucleation and/or growth of the tooeleite and

$\mathrm{As}(\mathrm{V})-\mathrm{Fe}(\mathrm{III})$ hydroxysulfate phases in a similar way. Moreover, these polymers might modify the surface properties of these As-containing phases and might foster their aggregation. Further experiments are however needed to address these possibilities.

Finally, it has been shown that microbial dissimilatory ferric iron reduction can take place in acidic media as AMD, involving a variety of heterotrophic acidophilic microorganisms (e.g., Johnson and McGinness, 1991; Bridge and Johnson, 2000; Baker and Banfield, 2003) that can use the organic carbon produced by autotrophic bacteria as electron donors (Clark and Norris, 1996). Moreover, anaerobic ferric iron respiration can be processed by chemolithoautotrophic acidophilic bacteria such as Acidithiobacillus ferrooxidans under anoxic conditions (Pronk et al., 1991). While this metabolism has not been studied in the Carnoulès AMD system, the close association of the electron acceptors $\mathrm{Fe}(\mathrm{III})$ and $\mathrm{As}(\mathrm{V})$ with organic car- bon polymers in the amorphous $\mathrm{Fe}-\mathrm{As}$ hydroxysulfate precipitate might provide a suitable substrate for heterotrophic metabolisms, provided that the anoxic conditions for these metabolisms would occur. However, such reductive metabolisms are not thought to constitute an alternative pathway for the formation of As(III)-containing phases in Carnoulès waters, since dissimilatory reduction of $\mathrm{As}(\mathrm{V})$ to $\mathrm{As}(\mathrm{III})$ has been only shown yet to be active in near-neutral and alkaline media (Macy et al., 1996; Newman et al., 1998; Stolz and Oremland, 1999; Gihring and Banfield, 2001; Oremland and Stolz, 2003; Kocar et al., 2006; Lloyd and Oremland, 2006). In contrast, processes involved in arsenic resistance, that are widespread in prokaryotes, and are based on arsenate reduction and arsenite efflux (Rosen, 2002), could favor the formation of As(III)-Fe(III) mineral phases, especially in the case of Acidithiobacillus ferrooxidans (Butcher et al., 2000; Duquesne et al., 2003).

\subsection{Vesicles}

The abundant mineralized vesicles detected on dried drops and on cross-sections in the Carnoulès AMD samples constitute another type of biomineral. While the discussion of their origin remains tentative, their resemblance in terms of texture and size to vesicles observed in several other studies is striking. Such vesicles have been observed, for example, in association with lollingite $\left(\mathrm{FeAs}_{2}\right)$ precipitation in hot springs in Japan (Tazaki et al., 2003). Such vesicles have been interpreted by these authors as parasitic or symbiotic bacteria. However, several lines of evidence indicate that they are not microbial cells. First, their size is smaller than that of any known bacterium. Moreover, the C K-edge NEXAFS spectra measured on the Carnoulès vesicles are not consistent with that of a bacterium because the spectra do not show any contribution from proteins at $288.2 \mathrm{eV}$. Similar spherules with a low electron density have also been observed by Ohnuki et al. (2004) (see Fig. 5b) in the Gunma AMD (Japan), in the Iron Mountain AMD (Baker et al., 2006), and in calcifying cultures of Gram-negative sulfatereducing bacteria (Aloisi et al., 2006). While they could be lysis products of bacterial cells formed during biomineralization (e.g., Benzerara et al., 2004b; Southam and Donald, 1999), we could also speculate that these vesicles resemble the outer membrane vesicles (OMV) produced by a wide variety of Gram-negative bacteria (Beveridge, 1999). These vesicles consist of outer membrane and periplasmic material and are released from the bacterial surface without loss of membrane integrity. It has been shown that they can be an abundant component of bacterial biofilms that has been overlooked until recently (Schooling and Beveridge, 2006; Matias and Beveridge, 2006). Some authors have proposed that they are released under conditions of stress (e.g., Nevot et al., 2006; McBroom and Kuehn, 2007), and it has also been suggested that they were used as new forms of secretions of various compounds such as virulence factors. The morphology of the vesicles (including their narrow size distribution) and the presence of bulges of similar size on the microbial cells from the Carnoulès AMD system might be consistent with vesiculation patterns. 
Finally, although not unambiguous, the $\mathrm{C}$ K-edge NEXAFS spectrum measured on these vesicles is consistent with that of reference membrane-forming lipids such as 1,2Diarachidonoyl-sn-Glycero-3-Phosphocholine measured by Dynes et al. (2006), with a major absorption feature at $288.7 \mathrm{eV}$ and another feature at $285.1 \mathrm{eV}$. Differences between these spectra might be interpreted either as being due to a different $\mathrm{C}$-containing molecule comprising the Carnoulès vesicles and/or to chemical variations subsequent to biomineralization occurring in the Carnoulès vesicles. Further studies using bacterial strains isolated from the Carnoulès AMD system will be needed to investigate the processes of biomineralization and to provide more definitive evidence for the potential involvement of OMV in the formation of these vesicles.

\section{CONCLUSIONS}

This study presents a microscopic characterization of both organics and mineral phases in the Carnoulès AMD system, characterized by exceptional As concentrations in the dissolved and solid phases (Morin and Calas, 2006). Both As(III)- and As(V)-Fe(III) hydroxysulfate minerals (respectively, tooeleite and an amorphous phase) previously identified as the main mineral phases of the Carnoulès sediments (Morin et al., 2003) were detected at the submicrometer-scale in intimate association with organic and biological components, by combining TEM and STXM at the As $\mathrm{L}_{3}$-edge analyses. Living and/or mineralized microbial cells were imaged. They were frequently associated with mineral precipitates, and a variety of biomineralization patterns were observed with precipitates forming either extracellularly or within the periplasm. Using STXM at the C K-edge, pervasive organic carbon was detected in association with the mineral precipitates observed in the Carnoulès AMD. Finally, abundant biomineralized organic vesicles resembling the outer membrane vesicles produced by Gram-negative bacteria were documented and may represent a significant biomineralization process in AMD systems.

\section{ACKNOWLEDGMENTS}

We gratefully acknowledge the support of CNRS Program "CNRS/Etats-Unis" (K.B. and G.M.), an ANR "Jeunes Chercheurs" Grant (K.B.), CNRS/INSU Program EC2CO (C.C., O.B., and G.M.), NSF Grant CHE-0431425 (K.B. and G.E.B.) (Stanford Environmental Molecular Science Institute) as well as support from the Stanford-France Collaborative Research Program at Stanford University (K.B. and G.E.B.). The work at the ALS and ALS BL 11.0.2 was supported in part by the Office of Science, Office of Basic Energy Sciences, Division of Materials Sciences, and Division of Chemical Sciences, Geosciences, and Biosciences of the U.S. Department of Energy at Lawrence Berkeley National Laboratory under contract No. DE-AC03-76SF00098. We thank Stefan Borenztajn for SEM analyses.

\section{APPENDIX A. SUPPLEMENTARY DATA}

SEM images, XRD and SAED pattern of the Carnoulès samples C12Ju105 and S32Ju105. Supplementary data asso- ciated with this article can be found, in the online version, at doi:10.1016/j.gca.2008.05.046.

\section{REFERENCES}

Akabayov B., Doonan C. J., Pickering I. J., George G. N. and Sagi I. (2005) Using softer X-ray absorption spectroscopy to probe biological systems. J. Synchrotron Rad. 12, 392-401.

Aloisi G., Gloter A., Kroger M., Wallmann K., Guyot F. and Zuddas P. (2006) Nucleation of calcium carbonate on bacterial nanoglobules. Geology 34, 1017-1020.

Baker B. J. and Banfield J. F. (2003) Microbial communities in acid mine drainage. FEMS Microbiol. Ecol. 44, 139-152.

Baker B. J., Tyson G. W., Webb R. I., Flanagan J., Hugenholtz P., Allen E. E. and Banfield J. F. (2006) Lineages of acidophilic archaea revealed by community genomic analysis. Science 314 , 1933-1935.

Battaglia-Brunet F., Itard Y., Garrido F., Delorme F., Crouzet C., Greffie C. and Joulian C. (2006) A simple biogeochemical process removing arsenic from a mine drainage water. Geomicrobiol. J. 23, 201-211.

Benzerara K., Yoon T. H., Tyliszczak T., Constantz B., Spormann A. M. and Brown, Jr., G. E. (2004a) Scanning transmission Xray microscopy study of microbial calcification. Geobiology 2, 249-259.

Benzerara K., Menguy N., Guyot F., Skouri F., de Luca G., Barakat M. and Heulin T. (2004b) Biologically controlled precipitation of calcium phosphate by Ramlibacter tataouinensis. Earth Planet. Sci. Lett. 228, 439-449.

Benzerara K., Menguy N., Lopez-Garcia P., Yoon T. H., Kazmierczak J., Tyliszczak T., Guyot F. and Brown, Jr., G. E. (2006) Nanoscale detection of organic signatures in carbonate microbialites. Proc. Natl. Acad. Sci. USA 103, 9440-9445.

Benzerara K., Menguy N., Banerjee N. R., Tyliszczak T., Guyot F. and Brown, Jr., G. E. (2007) Alteration of submarine basaltic glass from the Ontong Java Plateau: a STXM and TEM study. Earth Planet. Sci. Lett. 260, 187-200.

Beveridge T. J. (1999) Structures of Gram-negative cell walls and their derived membrane vesicles. J. Bacteriol. 181, 47254733.

Bigham J. M., Schwertmann U., Carlson L. and Murad E. (1990) A poorly crystallized oxyhydroxysulfate of iron formed by bacterial oxidation of $\mathrm{Fe}(\mathrm{II})$ in acid-mine waters. Geochim. Cosmochim. Acta 54, 2743-2758.

Bluhm H., Andersson K., Araki T., Benzerara K., Brown, Jr., G. E., Dynes J. J., Ghosal S., Gilles M. K., Hansen H. C., Hemminger J. C., Hitchcock A. P., Ketteler G., Kilcoyne A. L. D., Kneedler E., Lawrence J. R., Leppard G. G., Majzlam J., Mun B. S., Myneni S. C. B., Nilsson A., Ogasawara H., Ogletree D. F., Pecher K., Salmeron M., Shuh D. K., Tonner B., Tyliszczak T., Warwick T. and Yoon T. H. (2006) Soft Xray microscopy and spectroscopy at the molecular environmental science beamline at the Advanced Light Source. J. Electron Spectrosc. Related Phenom. 150, 86-104.

Bouchez T., Jacob P., d'Hugues P. and Durand A. (2006) Acidophilic microbial communities catalyzing sludge bioleaching monitored by fluorescent in situ hybridization. Antonie Van Leeuwenhoek Int. J. General Mol. Microbiol. 89, 435-442.

Brake S. S., Hasiotis S. T., Dannelly H. K. and Connors K. A. (2002) Eukaryotic stromatolite builders in acid mine drainage: implications for Precambrian iron formations and oxygenation of the atmosphere? Geology 30, 599-602.

Bridge T. A. M. and Johnson D. B. (2000) Reductive dissolution of ferric iron minerals by Acidiphilium SJH. Geomicrob. J. 17, 193-206.

Bruneel O., Personne' J. C., Casiot C., Leblanc M., Elbaz-Poulichet F., Mahler B. J., Le Flèche A. and Grimont P. A. D. (2003) 
Mediation of arsenic oxidation by Thiomonas sp. in acid-mine drainage (Carnoulès, France). J. Appl. Microbiol. 95, 492-499.

Bruneel O., Duran R., Casiot C., Elbaz-Poulichet F. and Personne' J. C. (2006) Diversity of microorganisms in Fe-As-rich acid mine drainage waters of Carnoulès, France. Appl. Environ. Microbiol. 72, 551-556.

Budinoff C. R. and Hollibaugh J. T. (2008) Arsenite-dependent photoautotrophy by an Ectothiorhodospira-dominated consortium. Int. Soc. Microb. Ecol. J. 2, 340-343.

Butcher B. G., Deane S. M. and Rawlings D. E. (2000) The chromosomal arsenic resistance genes of Thiobacillus ferrooxidans have an unusual arrangement and confer increased arsenic and antimony resistance to Escherichia coli. Appl. Environ. Microbiol. 66, 1826-1833.

Cances B., Juillot F., Morin G., Laperche V., Alvarez L., Proux O., Hazemann J. L., Brown, Jr., G. E. and Calas G. (2005) XAS evidence of $\mathrm{As}(\mathrm{V})$ association with iron oxyhydroxides in a contaminated soil at a former arsenical pesticide processing plant. Environ. Sci. Technol. 39, 9398-9405.

Carlson L., Bigham J. M., Schwertmann U., Kyek A. and Wagner F. (2002) Scavenging of As from acid mine drainage by schwertmannite and ferrihydrite: a comparison with synthetic analogues. Environ. Sci. Technol. 36, 1712-1719.

Casiot C., Morin G., Juillot F., Bruneel O., Personne' J. C., Leblanc M., Duquesne K., Bonnefoy V. and Elbaz-Poulichet F. (2003) Bacterial immobilisation and oxidation of arsenic in acid mine drainage (Carnoulès creek, France). Water Res. 37, 2929-2936.

Casiot C., Lebrun S., Morin G., Bruneel O., Personne' J. C. and Elbaz-Poulichet F. (2005) Sorption and redox processes controlling transport in a stream impacted by acid arsenic fate and mine drainage. Sci. Total Environ. 347, 122-130.

Cesbron F. P. and Williams S. A. (1992) Tooeleite, a new mineral from the United-States mine, Tooele County, Utah. Min. Mag. $56,71-73$.

Chan C. S., De Stasio G., Welch S. A., Girasole M., Frazer B. H., Nesterova M. V., Fakra S. and Banfield J. F. (2004) Microbial polysaccharides template assembly of nanocrystal fibers. Science $303,1656-1658$.

Clark D. A. and Norris P. R. (1996) Acidimicrobium ferrooxidans gen nov, sp. nov: mixed-culture ferrous iron oxidation with Sulfobacillus species. Microbiology 142, 785-790.

Clarke W. A., Konhauser K. O., Thomas J. C. and Bottrell S. H. (1997) Ferric hydroxide and ferric hydroxysulfate precipitation by bacteria in an acid mine drainage lagoon. FEMS Microbiol. Rev. 20, 351-361.

Dixit S. and Hering J. G. (2003) Comparison of arsenic(V) and arsenic(III) sorption onto iron oxide minerals: Implications for arsenic mobility. Environ. Sci. Technol. 37, 4182-4189.

Duquesne K., Lebrun S., Casiot C., Bruneel O., Personne' J. C., Leblanc M., Elbaz-Poulichet F., Morin G. and Bonnefoy V. (2003) Immobilization of arsenite and ferric iron by Acidithiobacillus ferrooxidans and its relevance to acid mine drainage. Appl. Environ. Microbiol. 69, 6165-6173.

Dupraz C. and Visscher P. T. (2005) Microbial lithification in marine stromatolites and hypersaline mats. Trends Microbiol. $13,429-438$.

Dynes J. J., Lawrence J. R., Korber D. R., Swerhone G. D. W., Leppard G. G. and Hitchcock A. P. (2006) Quantitative mapping of chlorhexidine in natural river biofilms. Sci. Total Environ. 369, 369-383.

Eary L. E. and Schramke J. A. (1990) Rates of inorganic oxidation reactions involving dissolved-oxygen. ACS Symp. Ser. 416, 379-396.

Evangelou V. P. and Zhang Y. L. (1995) A review-pyrite oxidation mechanisms and acid-mine drainage prevention. Crit. Rev. Environ. Sci. Technol. 25, 141-199.
Foster A. L. and Ashley R. P. (2002) Characterization of arsenic species in microbial mats from an inactive gold mine. Geochem.: Exploration Environ. Anal. 2, 253-261.

Gihring T. M. and Banfield J. F. (2001) Arsenite oxidation and arsenate respiration by a new Thermus isolate. FEMS Microbiol. Lett. 204, 335-340.

Haberstroh P. R., Brandes J. A., Gelinas Y., Dickens A. F., Wirick S. and Cody G. (2006) Chemical composition of the graphitic black carbon fraction in riverine and marine sediments at submicron scales using carbon X-ray spectromicroscopy. Geochim. Cosmochim. Acta 70, 1483-1494.

Hallberg R. and Ferris F. G. (2004) Biomineralization by Gallionella. Geomicrobiol. J. 21, 325-330.

Hitchcock A. P. (2001) Soft X-ray spectromicroscopy of polymers and biopolymer interfaces. J. Synchrotron Rad. 8, 66-71.

Ilyaletdinov A. N. and Abdrashitova S. A. (1981) Autotrophic oxidation of arsenic by a culture of Pseudomonas arsenitoxidans. Microbiology 50, 135-140.

Inskeep W. P., Macur R. E., Harrison G., Bostick B. C. and Fendorf S. (2004) Biomineralization of As(V)-hydrous ferric oxyhydroxide in microbial mats of an acid-sulfate-chloride geothermal spring, Yellowstone National Park. Geochim. Cosmochim. Acta 68, 3141-3155.

Inskeep W. P., Macur R. E., Hamamura N., Warelow T. P., Ward S. A. and Santini J. M. (2007) Detection, diversity and expression of aerobic bacterial arsenite oxidase genes. Environ. Microbiol. 9, 934-943.

Jacobsen C., Wirick S., Flynn G. and Zimba C. (2000) Soft X-ray spectroscopy from image sequences with sub-100 $\mathrm{nm}$ spatial resolution. J. Microsc. 197, 173-184.

Johnson D. B. and McGinness S. (1991) Ferric iron reduction by acidophilic heterotrophic bacteria. Appl. Environ. Microbiol. 57, 207-211.

Jones B. and Renaut R. W. (2007) Selective mineralization of microbes in Fe-rich precipitates (jarosite, hydrous ferric oxides) from acid hot springs in the Waiotapu geothermal area, North Island, New Zealand. Sedimen. Geol. 194, 77-98.

Kawano M. and Tomita K. (2001) Geochemical modeling of bacterially induced mineralization of schwertmannite and jarosite in sulfuric acid spring water. Am. Mineral. 86, 11561165.

Kocar B. D., Herbel M. J., Tufano K. J. and Fendorf S. (2006) Contrasting effects of dissimilatory iron(III) and arsenic(V) reduction on arsenic retention and transport. Environ. Sci. Technol. 40, 6715-6721.

Lawrence J. R., Swerhone G. D. W., Leppard G. G., Araki T., Zhang X., West M. M. and Hitchcock A. P. (2003) Scanning transmission X-ray, laser scanning, and transmission electron microscopy mapping of the exopolymeric matrix of microbial biofilms. Appl. Environ. Microbiol. 69, 5543-5554.

Lazaroff N., Sigal W. and Wasserman A. (1982) Iron oxidation and precipitation of ferric hydroxysulfates by resting Thiobacillus ferrooxidans cells. Appl. Environ. Microbiol. 43, 924-938.

Leblanc M., Achard B., Othman D. B., Luck J. M., BertrandSarfati J. and Personne' J. C. (1996) Accumulation of arsenic from acidic mine waters by ferruginous bacterial accretions (stromatolites). Appl. Geochem. 11, 541-554.

Lloyd J. R. and Oremland R. S. (2006) Microbial transformations of arsenic in the environment: from soda lakes to aquifers. Elements 2, 85-90.

Lo I., Denef V. J., VerBerkmoes N. C., Shah M. B., Goltsman D., DiBartolo G., Tyson G. W., Allen E. E., Ram R. J., Detter J. C., Richardson P., Thelen M. P., Hettich R. L. and Banfield J. F. (2007) Strain-resolved community proteomics reveals recombining genomes of acidophilic bacteria. Nature 446, 537-541. 
Lopez-Archilla A. I., Gerard E., Moreira D. and Lopez-Garcia P. (2004) Macrofilamentous microbial communities in the metalrich and acidic River Tinto, Spain. FEMS Microbiol. Lett. 235, 221-228.

Macy J. M., Nunan K., Hagen K. D., Dixon D. R., Harbour P. J., Cahill M. and Sly L. I. (1996) Chrysiogenes arsenatis gen nov, sp. nov; a new arsenate-respiring bacterium isolated from gold mine wastewater. Int. J. Syst. Bacteriol. 46, 1153-1157.

Matias V. R. F. and Beveridge T. J. (2006) Native cell wall organization shown by cryo-electron microscopy confirms the existence of a periplasmic space in Staphylococcus aureus. J. Bacteriol. 188, 1011-1021.

McBroom A. J. and Kuehn M. J. (2007) Release of outer membrane vesicles by Gram-negative bacteria is a novel envelope stress response. Mol. Microbiol. 63, 545-558.

Morin G., Juillot F., Casiot C., Bruneel O., Personne' J. C., ElbazPoulichet F., Leblanc M., Ildefonse P. and Calas G. (2003) Bacterial formation of tooeleite and mixed arsenic(III) or arsenic(V)-iron(III) gels in the Carnoulès acid mine drainage, France. A XANES, XRD, and SEM study. Environ. Sci. Technol. 37, 1705-1712.

Morin G. and Calas G. (2006) Arsenic in soils, mine tailings, and former industrial sites. Elements 2, 97-101.

Morin G., Rousse G. and Elkaim E. (2007) Crystal structure of tooeleite, $\mathrm{Fe}_{6}\left(\mathrm{AsO}_{3}\right)_{4} \mathrm{SO}_{4}(\mathrm{OH})_{4} 4 \mathrm{H}_{2} \mathrm{O}$, a new iron arsenite oxyhydroxysulfate mineral relevant to acid mine drainage. Am. Mineral. 92, 193-197.

Nevot M., Deroncele V., Messner P., Guinea J. and Mercade E. (2006) Characterization of outer membrane vesicles released by the psychrotolerant bacterium Pseudoalteromonas antarctica NF3. Environ. Microbiol. 8, 1523-1533.

Newman D. K., Ahmann D. and Morel F. M. M. (1998) A brief review of microbial arsenate respiration. Geomicrobiol. J. 15, 255-268.

Obst, M., Dittrich, M. and Kuehn, H. (2006) Calcium adsorption and changes of the surface microtopography of cyanobacteria studied by AFM, CFM, and TEM with respect to biogenic calcite nucleation. Geochem. Geophys. Geosystems 7, Art. No. Q06011.

Ohnuki T., Sakamoto F., Kozai N., Ozaki T., Yoshida T., Narumi I., Wakai E., Sakai T. and Francis A. J. (2004) Mechanisms of arsenic immobilization in a biomat from mine discharge water. Chem. Geol. 212, 279-290.

Ona-Nguema G., Morin G., Juillot F., Calas G. and Brown, Jr., G. E. (2005) Arsenite sorption onto 2-line ferrihydrite, hematite, goethite, and lepidocrocite under anoxic conditions: a XANES and EXAFS study. Environ. Sci. Technol. 39, 9147-9155.

Oremland R. S. and Stolz J. F. (2003) The ecology of arsenic. Science 300, 939-944.

Phoenix V. R., Renaut R. W., Jones B. and Ferris F. G. (2005) Bacterial S-layer preservation and rare arsenic-antimony-sulphide bioimmobilization in siliceous sediments from Champagne Pool hot spring, Waiotapu, New Zealand. J. Geol. Soc. $162,323-331$.
Polizzotto M. L., Harvey C. F., Li G. C., Badruzzman B., Ali A., Newville M., Sutton S. and Fendorf S. (2006) Solid-phases and desorption processes of arsenic within Bangladesh sediments. Chem. Geol. 228, 97-111.

Pronk J. T., Liem K., Bos P. and Kuenen J. G. (1991) Energy transduction by anaerobic ferric iron respiration in Thiobacillus ferrooxidans. Appl. Environ. Microbiol. 57, 2063-2068.

Rosen B. P. (2002) Biochemistry of arsenic detoxication. FEBS Lett. 529, 86-92.

Simeonova D. D., Lievremont D., Lagarde F., Muller D. A. E., Groudeva V. I. and Lett M. C. (2004) Microplate screening assay for the detection of arsenite-oxidizing and arsenatereducing bacteria. FEMS Microbiol. Lett. 237, 249-253.

Schooling S. R. and Beveridge T. J. (2006) Membrane vesicles: an overlooked component of the matrices of biofilms. J. Bacteriol. $188,5945-5957$.

Schumacher M., Christl I., Scheinost A. C., Jacobsen C. and Kretzschmar R. (2005) Chemical heterogeneity of organic soil colloids investigated by scanning transmission X-ray microscopy and C-1s NEXAFS microspectroscopy. Environ. Sci. Technol. 39, 9094-9100.

Stolz J. F. and Oremland R. S. (1999) Bacterial respiration of arsenic and selenium. FEMS Microbiol. Rev. 23, 615-627.

Southam G. and Donald R. (1999) A structural comparison of bacterial microfossils vs. 'nanobacteria' and nanofossils. Earth Sci. Rev. 48, 251-264.

Tazaki K., Rafiqul I. A. B. M., Nagai K. and Kurihara T. (2003) FeAs biomineralization on encrusted bacteria in hot springs: an ecological role of symbiotic bacteria. Can. J. Earth Sci. 40, $1725-1738$.

Thoral S., Rose J., Garnier J. M., Van Geen A., Refait P., Traverse A., Fonda E., Nahon D. and Bottero J. Y. (2005) XAS study of iron and arsenic speciation during $\mathrm{Fe}$ (II) oxidation in the presence of As(III). Environ. Sci. Technol. 39, 9478-9485.

Wang H. M., Bigham J. M., Jones F. S. and Tuovinen O. H. (2007) Synthesis and properties of ammoniojarosites prepared with iron-oxidizing acidophilic microorganisms at 22-65 degrees C. Geochim. Cosmochim. Acta 71, 155-164.

Williams M. (2001) Arsenic in mine waters: an international study. Environ. Geol. 40, 267-278.

Yoon T. H., Johnson S. B., Benzerara K., Doyle C. S., Tyliszczak T., Shuh D. K. and Brown, Jr., G. E. (2004) In situ characterization of aluminum-containing nanoparticle-aqueous suspensions using scanning transmission X-ray microscopy. Langmuir 20, 10361-10366.

Yoon T. H., Benzerara K., Ahn S., Luthy R. G., Tyliszczak T. and Brown, Jr., G. E. (2006) Nanometer-scale chemical heterogeneities of black carbon materials and their impacts on PCB sorption properties: soft X-ray spectromicroscopy study. Environ. Sci. Technol. 40, 5923-5929. 